\title{
Ternary Complexes of $\mathrm{Cd}(\mathrm{II})$ Involving Pyridine-2-carboxylic Acid and Biorelevant Ligands
}

\author{
Eman M. Shoukry, Nagda G. Hosny, Mona F. Amin and \\ Eman F. Mohamed \\ Department of Chemistry, Faculty of Science (Girls), Al Azhar \\ University, Nasr City, Cairo, Egypt.
}

\begin{abstract}
COMPLEX formation reactions involving Cd(II), pyridine -2carboxylic acid ( picolinic acid, PA) and various biorelevant ligands (L) containing different functional groups are investigated at $25^{\circ} \mathrm{C}$ and $I=0.10 \mathrm{M}\left(\mathrm{NaNO}_{3}\right)$. The ligands (L) used are amino acids, peptides and DNA constituents. The results showed the formation of $\mathrm{Cd}(\mathrm{II})-(\mathrm{PA})-(\mathrm{L})$ complexes with amino acids and DNA constituents, peptides form both $\mathrm{Cd}(\mathrm{II})-(\mathrm{PA})-(\mathrm{L})$ complexes and the corresponding deprotonated amide species $\mathrm{Cd}(\mathrm{II})-(\mathrm{PA})-$ $\left(\mathrm{LH}_{-1}\right)$. The relative stabilities of ternary complexes are compared with those of the corresponding binary complexes in terms of $\Delta \log K$ values. The concentration distribution of the complexes in solution was evaluated.
\end{abstract}

Keywords: Cd(II), Picolinic acid, Amino acids, Peptides, DNA constituents, Stability constant.

The great majority of the work of biological chemists is concerned with the coordination chemistry of essential metal ions in living organisms, and the examination of aspects of the interactions of these essential metal ions with the rest of the enzymes of the cells in which they are found. The present study, however, is concerned with the manipulation of the coordination environment of toxic metal ions in order to accelerate their excretion from the organism. The toxic effects of cadmium (II) are well documented ${ }^{(1)}$. They have been found to induce various pathological conditions detected including cardiovascular diseases (2), hypertension ${ }^{(3)}$, and some forms of cancer. The toxicology of cadmium (II) is often governed by its interaction with an abundance of certain potential ligands in biological systems ${ }^{(4-7)}$. In animals, $\mathrm{Cd}(\mathrm{II})$ accumulates mainly in the liver and kidney, where it is largely bound to thionein, a sulphur-rich protein ${ }^{(8-10)}$. In red blood cells, $\mathrm{Cd}(\mathrm{II})$ has been shown to become complexed by GSH (glutathione) and haemoglobin ${ }^{(11)}$. The goal of chelating agent treatment of metal intoxication is to transform a toxic metal bound to a constituent (usually a protein) of a living organism into a less toxic metal chelate which is readily excreted. In discussing chelating agent design, it was reported that stability constant has long been recognized as a key factor in the 
determination of the ability of the chelating agent to remove the metal from living organism ${ }^{(12,13)}$. In the course of the search for a new antidote for cadmium, picolinic acid was found to form stable complex with $\mathrm{Cd}(\mathrm{II})$ ion. Hence, it seems interesting to study the formation equilibrium of $\mathrm{Cd}(\mathrm{II})$ picolinic acid( pyridine -2- carboxylic acid) complex and to investigate its interaction with other ligands commonly exist in biological fluids. In continuation of our studies on the binary and ternary complexes of biological significance $^{(14-22)}$, the present paper traces the formation and characterization of the binary and ternary complexes involving $\mathrm{Cd}(\mathrm{II})$, pyridine -2- carboxylic acid (picolinic acid) and other ligands, such as amino acids, peptides and DNA constituents .

\section{Materials}

\section{Experimental}

Picolinic acid (PA) was obtained from Sigma Chem. Co. Glycine, alanine, phenylalanine, valine, proline, threonine, serine, lysine, L- histamine $2 \mathrm{HCl}$, Lhistidine $\cdot \mathrm{HCl}$, L-ornithine, methionine, S-methylcysteine and imidazole were provided by the Sigma Chem. Co. The peptides used were glycylglycine, glutamine, aspargine and glycinamide also provided by Sigma Chem. Co. The DNA constituents uracil, uridine, inosine, inosine -5-monophosphat (IMP), adenine, guanosine and guanosine -5 -monophosphate (GMP) were supplied by BDH-Biochemicals Ltd. Cadmium(II) nitrate was provided by Aldrich. The cadmium content of solution was estimated complexometrically ${ }^{(23)}$. Carbonate free $\mathrm{NaOH}$ (titrant) was prepared and standardized daily against a potassium hydrogen phthalate solution. All solutions were prepared in deionized $\mathrm{H}_{2} \mathrm{O}$.

\section{Apparatus}

Potentiometric measurements were made using a Metrohm 751 titroprosessor. The electrode and titroprocessor were calibrated using potassium hydrogen phthalate $(\mathrm{pH}=4.008)$ and phosphate $(\mathrm{pH}=6.865)$ buffers prepared according to NBS specifications ${ }^{(24)}$. All pH-metric titrations were carried out at $25.0^{\circ} \mathrm{C}, \mathrm{I}=0.10 \mathrm{M}\left(\mathrm{NaNO}_{3}\right)$, in a purified nitrogen atmosphere using a titration vessel described previously ${ }^{(25)}$.

\section{Procedure and measuring techniques}

The acid dissociation constants of the ligands were determined potentiometrically by titrating the ligand $\left(40 \mathrm{~cm}^{3}\right)$ solution $\left(1.25 \times 10^{-3}\right.$ $\mathrm{mol} \cdot \mathrm{L}^{-1}$ ) of constant ionic strength $0.1 \mathrm{~mol} \cdot \mathrm{L}^{-1}$, adjusted with $\mathrm{NaNO}_{3}$. The stability constant of the $\mathrm{Cd}(\mathrm{PA})$ complex was determined by titrating $40 \mathrm{~cm}^{3}$ of a solution mixture of $\mathrm{Cd}(\mathrm{II})\left(1.25 \times 10^{-3} \mathrm{~mol} \cdot \mathrm{L}^{-1}\right)$, PA ligand $\left(1.25 \times 10^{-3} \mathrm{~mol} \cdot \mathrm{L}^{-1}\right)$ and $\mathrm{NaNO}_{3}\left(0.1 \mathrm{~mol} \cdot \mathrm{L}^{-1}\right)$. The formation constants of the mixed ligand complexes were determined by titrating solution mixtures containing equivalent amounts of $\mathrm{Cd}(\mathrm{II})\left(1.25 \times 10^{-3} \mathrm{~mol} \cdot \mathrm{L}^{-1}\right)$, (PA) and other ligands in the concentration ratio 1:1:1 for amino acids and peptides, and 1:1:2 for the DNA constituents. All titrations were performed in a purified $\mathrm{N}_{2}$ atmosphere using aqueous $0.05 \mathrm{~mol} \cdot \mathrm{L}^{-1} \mathrm{NaOH}$ as titrant.

Egypt. J. Chem. 59, No. 5 (2016) 
The general four component equilibrium can be written as Eq. (1) and (2) (charges are omitted for simplicity):

$$
\begin{aligned}
& l(\mathrm{Cd})+p(\mathrm{PA})+q(\mathrm{~L})+r(\mathrm{H})=(\mathrm{Cd})_{l}(\mathrm{PA})_{p}(\mathrm{~L})_{q}(\mathrm{H})_{r} \\
& \beta_{\text {Ipqr }}=\frac{\left[\mathrm{Cd}_{1} \mathrm{PA}_{\mathrm{p}} \mathrm{L}_{\mathrm{q}} \mathrm{H}_{\mathrm{r}}\right]}{[\mathrm{Cd}]^{l}[\mathrm{PA}]^{\mathrm{p}}[\mathrm{L}]^{\mathrm{q}}[\mathrm{H}]^{\mathrm{r}}}
\end{aligned}
$$

The calculations were obtained from ca. 100 data points in each titration using the computer program MINIQUAD-75 (26). The stoichiometries and stability constants of the complexes formed were determined by trying various possible composition models. The results obtained are shown in Tables 1, 2. The concentration distribution diagrams were obtained using the program SPECIES ${ }^{(27)}$ under the experimental condition used.

\section{Results and Discussion}

The acid dissociation constants of the ligands were determined at $25.0^{\circ} \mathrm{C}$ and $\mathrm{I}=0.10 \mathrm{M}\left(\mathrm{NaNO}_{3}\right)$ under the same experimental conditions used to study the $\mathrm{Cd}(\mathrm{II})$-picolinic acid and the corresponding ternary complexes. The values were given in Tables $1 \& 2$.

\section{Formation equilibria of binary $C d(I I)-P A$ complexes}

Potentiometric titration curves of PA in presence and absence of $\mathrm{Cd}(\mathrm{II})$ ion are shown in Fig.1. In the metal complex curve, there is a significant lowering from that of the free picolinic acid, indicating formation of metal complexes by release of protons. Equilibrium models have been tried to fit the experimental potentiometric data for the $\mathrm{Cd}-(\mathrm{PA})$. The model that best fits the potentiometric data is found to consist of $\mathrm{Cd}-(\mathrm{PA})$.

The concentration distribution diagram of various species as a function of $\mathrm{pH}$ is depicted in Fig. 2. The concentration of the Cd(II)-PA species (110) increases with increasing $\mathrm{pH}$ and attains a maximum of $91 \%$ at $\mathrm{pH} \sim 6$. The main species present under physiological condition is calculated to be 110 which may be able to pass through cellular membranes. 
TABLE 1. Stability constants of binary systems Cd(II)-PA, Cd(II)-L and protonassociation constants at $25^{\circ} \mathrm{C}$ and $I=0.1 \mathrm{M} \mathrm{NaNO}_{3}$

\begin{tabular}{|c|c|c|c|c|c|}
\hline System & $\mathbf{l}$ & $\mathbf{P}$ & $\mathbf{q}$ & $\mathbf{r}^{\mathrm{a}}$ & $\log \beta^{b}$ \\
\hline Picolinic acid (PA) & $\begin{array}{l}0 \\
0 \\
1\end{array}$ & $\begin{array}{l}1 \\
1 \\
1\end{array}$ & $\begin{array}{l}0 \\
0 \\
0\end{array}$ & $\begin{array}{l}1 \\
2 \\
0\end{array}$ & $\begin{array}{c}5.22(0.008) \\
6.74(0.04) \\
5.12(0.12)\end{array}$ \\
\hline Glycine & $\begin{array}{l}0 \\
0 \\
1 \\
1\end{array}$ & $\begin{array}{l}0 \\
0 \\
0 \\
0\end{array}$ & $\begin{array}{l}1 \\
1 \\
1 \\
2\end{array}$ & $\begin{array}{l}1 \\
2 \\
0 \\
0\end{array}$ & $\begin{array}{c}9.64(0.01) \\
12.17(0.02) \\
7.82(0.02) \\
13.91(0.04)\end{array}$ \\
\hline Alanine & $\begin{array}{l}0 \\
0 \\
1 \\
1\end{array}$ & $\begin{array}{l}0 \\
0 \\
0 \\
0\end{array}$ & $\begin{array}{l}1 \\
1 \\
1 \\
2\end{array}$ & $\begin{array}{l}1 \\
2 \\
0 \\
0\end{array}$ & $\begin{array}{c}9.80(0.01) \\
12.62(0.03) \\
7.55(0.01) \\
13.36(0.03)\end{array}$ \\
\hline Valine & $\begin{array}{l}0 \\
0 \\
1 \\
1\end{array}$ & $\begin{array}{l}0 \\
0 \\
0 \\
0\end{array}$ & $\begin{array}{l}1 \\
1 \\
1 \\
2\end{array}$ & $\begin{array}{l}1 \\
2 \\
0 \\
0\end{array}$ & $\begin{array}{c}9.68(0.00) \\
12.18(0.01) \\
8.65(0.02) \\
14.16(0.03)\end{array}$ \\
\hline Proline & $\begin{array}{l}0 \\
0 \\
1 \\
1\end{array}$ & $\begin{array}{l}0 \\
0 \\
0 \\
0\end{array}$ & $\begin{array}{l}1 \\
1 \\
1 \\
2\end{array}$ & $\begin{array}{l}1 \\
2 \\
0 \\
0\end{array}$ & $\begin{array}{c}10.65(0.009) \\
13.18(0.01) \\
9.35(0.02) \\
15.67(0.02)\end{array}$ \\
\hline$\beta$ phenylalanine & $\begin{array}{l}0 \\
0 \\
1 \\
1\end{array}$ & $\begin{array}{l}0 \\
0 \\
0 \\
0\end{array}$ & $\begin{array}{l}1 \\
1 \\
1 \\
2\end{array}$ & $\begin{array}{l}1 \\
2 \\
0 \\
0\end{array}$ & $\begin{array}{c}9.20(0.01) \\
11.81(0.03) \\
8.29(0.02) \\
13.34(0.03)\end{array}$ \\
\hline Methionine & $\begin{array}{l}0 \\
0 \\
1 \\
1\end{array}$ & $\begin{array}{l}0 \\
0 \\
0 \\
0\end{array}$ & $\begin{array}{l}1 \\
1 \\
1 \\
2\end{array}$ & $\begin{array}{l}1 \\
2 \\
0 \\
0\end{array}$ & $\begin{array}{c}9.23(0.02) \\
12.04(0.04) \\
7.40(0.02) \\
13.98(0.01)\end{array}$ \\
\hline S-methylcysteine & $\begin{array}{l}0 \\
1 \\
1\end{array}$ & $\begin{array}{l}0 \\
0 \\
0\end{array}$ & $\begin{array}{l}1 \\
1 \\
2\end{array}$ & $\begin{array}{l}1 \\
0 \\
0\end{array}$ & $\begin{array}{c}8.65(0.02) \\
7.48(0.01) \\
13.76(0.03)\end{array}$ \\
\hline Threonine & $\begin{array}{l}0 \\
0 \\
1 \\
1 \\
1\end{array}$ & $\begin{array}{l}0 \\
0 \\
0 \\
0 \\
0\end{array}$ & $\begin{array}{l}1 \\
1 \\
1 \\
2 \\
1\end{array}$ & $\begin{array}{c}1 \\
2 \\
0 \\
0 \\
-1\end{array}$ & $\begin{array}{c}9.06(0.009) \\
11.07(0.03) \\
8.11(0.02) \\
14.56(0.01) \\
-0.55(0.02)\end{array}$ \\
\hline Serine & $\begin{array}{l}0 \\
0 \\
1 \\
1 \\
1\end{array}$ & $\begin{array}{l}0 \\
0 \\
0 \\
0 \\
0\end{array}$ & $\begin{array}{l}1 \\
1 \\
1 \\
2 \\
1\end{array}$ & $\begin{array}{c}1 \\
2 \\
0 \\
0 \\
-1\end{array}$ & $\begin{array}{c}9.17(0.01) \\
11.54(0.03) \\
8.06(0.02) \\
14.49(0.04) \\
-0.57(0.01)\end{array}$ \\
\hline Ornithine & $\begin{array}{l}0 \\
0 \\
0 \\
1 \\
1 \\
1\end{array}$ & $\begin{array}{l}0 \\
0 \\
0 \\
0 \\
0 \\
0\end{array}$ & \begin{tabular}{l|l}
1 & \\
1 & \\
1 & \\
1 & \\
2 & \\
1 &
\end{tabular} & $\begin{array}{l}1 \\
2 \\
3 \\
0 \\
0 \\
1\end{array}$ & $\begin{array}{c}10.58(0.03) \\
19.43(0.04) \\
20.98(0.05) \\
10.41(0.04) \\
15.67(0.02) \\
18.96(0.03)\end{array}$ \\
\hline
\end{tabular}

Egypt. J. Chem. 59, No. 5 (2016) 
TABLE 1. Cont.

\begin{tabular}{|c|c|c|c|c|c|}
\hline System & 1 & $\mathbf{P}$ & $\mathbf{q}$ & $\mathbf{r}^{\mathrm{a}}$ & $\log \beta^{b}$ \\
\hline Lysine & $\begin{array}{l}0 \\
0 \\
1 \\
1 \\
1\end{array}$ & $\begin{array}{l}0 \\
0 \\
0 \\
0 \\
0\end{array}$ & $\begin{array}{l}1 \\
1 \\
1 \\
2 \\
1\end{array}$ & $\begin{array}{l}1 \\
2 \\
0 \\
0 \\
1\end{array}$ & $\begin{array}{l}10.44(0.03) \\
19.66(0.02) \\
10.34(0.05) \\
15.81(0.04) \\
19.42(0.02)\end{array}$ \\
\hline Histidine & $\begin{array}{l}0 \\
0 \\
0 \\
1 \\
1 \\
1\end{array}$ & $\begin{array}{l}0 \\
0 \\
0 \\
0 \\
0 \\
0\end{array}$ & \begin{tabular}{l|l}
1 & \\
1 & \\
1 & \\
1 & \\
2 & \\
1 &
\end{tabular} & $\begin{array}{l}1 \\
2 \\
3 \\
0 \\
0 \\
1\end{array}$ & $\begin{array}{c}9.48(0.01) \\
15.76(0.01) \\
17.92(0.04) \\
9.94(0.01) \\
15.32(0.03) \\
19.23(0.01)\end{array}$ \\
\hline Histamine & $\begin{array}{l}0 \\
0 \\
1 \\
1 \\
1\end{array}$ & $\begin{array}{l}0 \\
0 \\
0 \\
0 \\
0\end{array}$ & \begin{tabular}{l|l}
1 \\
1 \\
1 \\
2 \\
1
\end{tabular} & $\begin{array}{l}1 \\
2 \\
0 \\
0 \\
1\end{array}$ & $\begin{array}{c}9.88(0.03) \\
15.94(0.05) \\
9.91(0.02) \\
15.16(0.05) \\
18.33(0.03)\end{array}$ \\
\hline Glycylglycine & $\begin{array}{l}0 \\
0 \\
1 \\
1\end{array}$ & $\begin{array}{l}0 \\
0 \\
0 \\
0\end{array}$ & $\begin{array}{l}1 \\
1 \\
1 \\
1\end{array}$ & $\begin{array}{c}1 \\
2 \\
0 \\
-1\end{array}$ & $\begin{array}{c}8.26(0.009) \\
11.44(0.02) \\
6.90(0.01) \\
1.86(0.02)\end{array}$ \\
\hline Glycinamide & $\begin{array}{l}0 \\
1 \\
1\end{array}$ & $\begin{array}{l}0 \\
0 \\
0\end{array}$ & $\begin{array}{l}1 \\
1 \\
1\end{array}$ & $\begin{array}{c}1 \\
0 \\
-1\end{array}$ & $\begin{array}{l}8.06(0.01) \\
5.41(0.01) \\
0.96(0.02)\end{array}$ \\
\hline Glutamine & $\begin{array}{l}0 \\
1 \\
1\end{array}$ & $\begin{array}{l}0 \\
0 \\
0\end{array}$ & $\begin{array}{l}1 \\
1 \\
1\end{array}$ & $\begin{array}{c}1 \\
0 \\
-1\end{array}$ & $\begin{array}{l}8.99(0.03) \\
8.73(0.04) \\
2.00(0.01)\end{array}$ \\
\hline Aspargine & $\begin{array}{l}0 \\
1 \\
1\end{array}$ & $\begin{array}{l}0 \\
0 \\
0\end{array}$ & $\begin{array}{l}1 \\
1 \\
1\end{array}$ & $\begin{array}{c}1 \\
0 \\
-1\end{array}$ & $\begin{array}{l}8.56(0.03) \\
7.50(0.04) \\
1.83(0.01)\end{array}$ \\
\hline Inosine & $\begin{array}{l}0 \\
1\end{array}$ & $\begin{array}{l}0 \\
0\end{array}$ & $\begin{array}{l}1 \\
1\end{array}$ & $\begin{array}{l}1 \\
0\end{array}$ & $\begin{array}{ll}8.80 & (0.01) \\
5.49 & (0.02)\end{array}$ \\
\hline Inosine-5?-monophosphate & $\begin{array}{l}0 \\
0 \\
1\end{array}$ & $\begin{array}{l}0 \\
0 \\
0\end{array}$ & $\begin{array}{l}1 \\
1 \\
1\end{array}$ & $\begin{array}{l}1 \\
2 \\
0\end{array}$ & $\begin{array}{rr}9.02 & (0.01) \\
15.24 & (0.01) \\
5.76 & (0.03)\end{array}$ \\
\hline Uracil & $\begin{array}{l}0 \\
1\end{array}$ & $\begin{array}{l}0 \\
0\end{array}$ & $\begin{array}{l}1 \\
1\end{array}$ & $\begin{array}{l}1 \\
0\end{array}$ & $\begin{array}{l}9.18(0.03) \\
6.02(0.04)\end{array}$ \\
\hline Uridine & $\begin{array}{l}0 \\
1\end{array}$ & $\begin{array}{l}0 \\
0\end{array}$ & $\begin{array}{l}1 \\
1\end{array}$ & $\begin{array}{l}1 \\
0\end{array}$ & $\begin{array}{l}9.01(0.03) \\
5.88(0.04)\end{array}$ \\
\hline Adenine & $\begin{array}{l}0 \\
0 \\
1\end{array}$ & $\begin{array}{l}0 \\
0 \\
0\end{array}$ & $\begin{array}{l}1 \\
1 \\
1\end{array}$ & $\begin{array}{l}1 \\
2 \\
0\end{array}$ & $\begin{array}{r}9.65(0.03) \\
13.90(0.04) \\
6.74(0.01)\end{array}$ \\
\hline Guanosine & $\begin{array}{l}0 \\
0 \\
1\end{array}$ & $\begin{array}{l}0 \\
0 \\
0\end{array}$ & $\begin{array}{l}1 \\
1 \\
1\end{array}$ & $\begin{array}{l}1 \\
2 \\
0\end{array}$ & $\begin{array}{c}9.13(0.01) \\
11.11(0.01) \\
5.41(0.01)\end{array}$ \\
\hline Guanosine-5?-monophosphate & $\begin{array}{l}0 \\
0 \\
1\end{array}$ & $\begin{array}{l}0 \\
0 \\
0\end{array}$ & $\begin{array}{l}1 \\
1 \\
1\end{array}$ & $\begin{array}{l}1 \\
2 \\
0\end{array}$ & $\begin{array}{c}9.48(0.01) \\
15.81(0.02) \\
5.51(0.01)\end{array}$ \\
\hline
\end{tabular}

${ }^{a} l, p, q$ and $r$ are the stoichiometric coefficient corresponding to Cd(II), PA, (bioactive ligands) and $\mathrm{H}^{+}$, respectively.

${ }^{\mathrm{b}}$ Standard deviations are given in parentheses. 
TABLE 2. Stability constants of the ternary species in the Cd(II)-PA-L systems at $25^{\circ} \mathrm{C}$ and $I=0.1 \mathrm{M} \mathrm{NaNO}_{3}$

\begin{tabular}{|c|c|c|c|c|c|c|}
\hline System & 1 & $\mathbf{p}$ & $\mathbf{q}$ & $\mathbf{r}^{\mathbf{a}}$ & $\log \beta^{b}$ & $\Delta \log K$ \\
\hline Glycine & 1 & 1 & 1 & 0 & $13.20(0.03)$ & 0.26 \\
\hline Alanine & 1 & 1 & 1 & 0 & $13.01(0.03)$ & 0.34 \\
\hline Valine & 1 & 1 & 1 & 0 & $13.90(0.02)$ & 0.33 \\
\hline Proline & 1 & 1 & 1 & 0 & $14.80(0.02)$ & 0.13 \\
\hline$\beta$ phenyl alanine & 1 & 1 & 1 & 0 & $13.50(0.04)$ & 0.03 \\
\hline Methionine & 1 & 1 & 1 & 0 & $12.66(0.01)$ & 0.14 \\
\hline S-methylcysteine & 1 & 1 & 1 & 0 & $12.83(0.02)$ & 0.23 \\
\hline Threonine & $\begin{array}{l}1 \\
1\end{array}$ & $\begin{array}{l}1 \\
1\end{array}$ & $\begin{array}{l}1 \\
1\end{array}$ & $\begin{array}{c}0 \\
-1\end{array}$ & $\begin{array}{c}13.40(0.04) \\
5.34(0.01)\end{array}$ & $\begin{array}{l}0.17 \\
0.77\end{array}$ \\
\hline Serine & $\begin{array}{l}1 \\
1\end{array}$ & $\begin{array}{l}1 \\
1\end{array}$ & $\begin{array}{l}1 \\
1\end{array}$ & $\begin{array}{c}0 \\
-1\end{array}$ & $\begin{array}{c}13.29(0.01) \\
5.30(0.03)\end{array}$ & $\begin{array}{l}0.11 \\
0.75\end{array}$ \\
\hline Ornithine & $\begin{array}{l}1 \\
1\end{array}$ & $\begin{array}{l}1 \\
1\end{array}$ & $\begin{array}{l}1 \\
1\end{array}$ & $\begin{array}{l}0 \\
1\end{array}$ & $\begin{array}{l}16.63(0.01) \\
25.10(0.02)\end{array}$ & $\begin{array}{l}1.10 \\
1.02\end{array}$ \\
\hline Lysine & $\begin{array}{l}1 \\
1\end{array}$ & $\begin{array}{l}1 \\
1\end{array}$ & $\begin{array}{l}1 \\
1\end{array}$ & $\begin{array}{l}0 \\
1\end{array}$ & $\begin{array}{l}16.61(0.01) \\
25.03(0.02)\end{array}$ & $\begin{array}{l}1.15 \\
0.49\end{array}$ \\
\hline Histidine & $\begin{array}{l}1 \\
1\end{array}$ & $\begin{array}{l}1 \\
1\end{array}$ & $\begin{array}{l}1 \\
1\end{array}$ & $\begin{array}{l}0 \\
1\end{array}$ & $\begin{array}{l}15.70(0.01) \\
24.53(0.01)\end{array}$ & $\begin{array}{l}0.64 \\
0.18\end{array}$ \\
\hline Histamine & $\begin{array}{l}1 \\
1\end{array}$ & $\begin{array}{l}1 \\
1\end{array}$ & $\begin{array}{l}1 \\
1\end{array}$ & $\begin{array}{l}0 \\
1\end{array}$ & $\begin{array}{l}15.08(0.01) \\
24.11(0.02)\end{array}$ & $\begin{array}{l}0.05 \\
0.66\end{array}$ \\
\hline Glycylglycine & 1 & 1 & 1 & 0 & $11.81(0.03)$ & -0.21 \\
\hline & 1 & 1 & 1 & -1 & $5.99(0.02)$ & -0.99 \\
\hline & 1 & 1 & 1 & -2 & $-2.75(0.03)$ & \\
\hline Glycinamide & 1 & 1 & 1 & 0 & $10.13(0.02)$ & -0.4 \\
\hline & 1 & 1 & 1 & -1 & $5.01(0.01)$ & -1.07 \\
\hline & 1 & 1 & 1 & -2 & $-4.32(0.02)$ & \\
\hline Glutamine & 1 & 1 & 1 & 0 & $12.95(0.03)$ & -0.9 \\
\hline & $\begin{array}{l}1 \\
1\end{array}$ & $\begin{array}{l}1 \\
1\end{array}$ & $\begin{array}{l}1 \\
1\end{array}$ & $\begin{array}{l}-1 \\
-2\end{array}$ & $\begin{array}{c}6.09(0.05) \\
-3.47(0.07)\end{array}$ & -1.03 \\
\hline Aspargine & $\begin{array}{l}1 \\
1 \\
1 \\
\end{array}$ & $\begin{array}{l}1 \\
1 \\
1\end{array}$ & $\begin{array}{l}1 \\
1 \\
1\end{array}$ & $\begin{array}{r}0 \\
-1 \\
-2 \\
\end{array}$ & $\begin{array}{c}12.12(0.03) \\
5.94(0.02) \\
-3.30(0.04)\end{array}$ & $\begin{array}{l}-0.5 \\
-1.01\end{array}$ \\
\hline Inosine & 1 & 1 & 1 & 0 & $11.11(0.03)$ & 0.50 \\
\hline Inosine-5?-monophosphate & 1 & 1 & 1 & 0 & $11.51(0.03)$ & 0.63 \\
\hline Uracil & 1 & 1 & 1 & 0 & $11.97(0.02)$ & 0.83 \\
\hline Uridine & 1 & 1 & 1 & 0 & $11.35(0.03)$ & 0.3 \\
\hline Adenine & 1 & 1 & 1 & 0 & $12.88(0.03)$ & 1.02 \\
\hline Guanosine & 1 & 1 & 1 & 0 & $10.87(0.03)$ & 0.34 \\
\hline Guanosine-5?-monophosphate & 1 & 1 & 1 & 0 & $11.02(0.03)$ & 0.40 \\
\hline
\end{tabular}

${ }^{\mathrm{a}} l, p, q$ and $r$ are the stoichiometric coefficient corresponding to Cd(II), PA, (bioactive ligands) and $\mathrm{H}^{+}$, respectively.

${ }^{\mathrm{b}}$ Standard deviations are given in parentheses.

Egypt. J. Chem. 59, No. 5 (2016) 


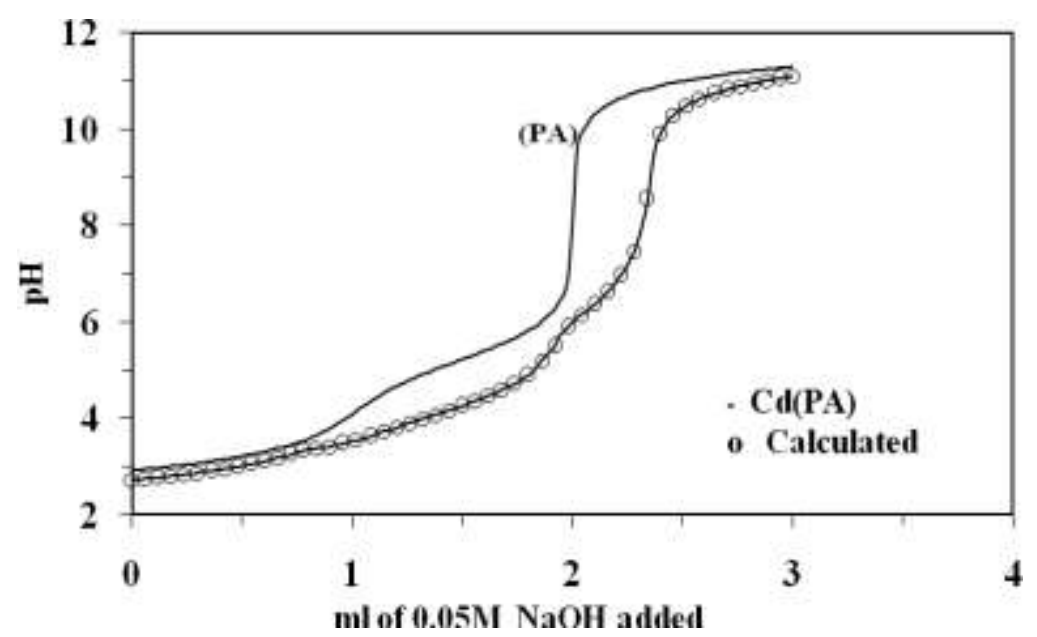

Fig.1. Potentiometric titration curve of Cd-(PA) system .

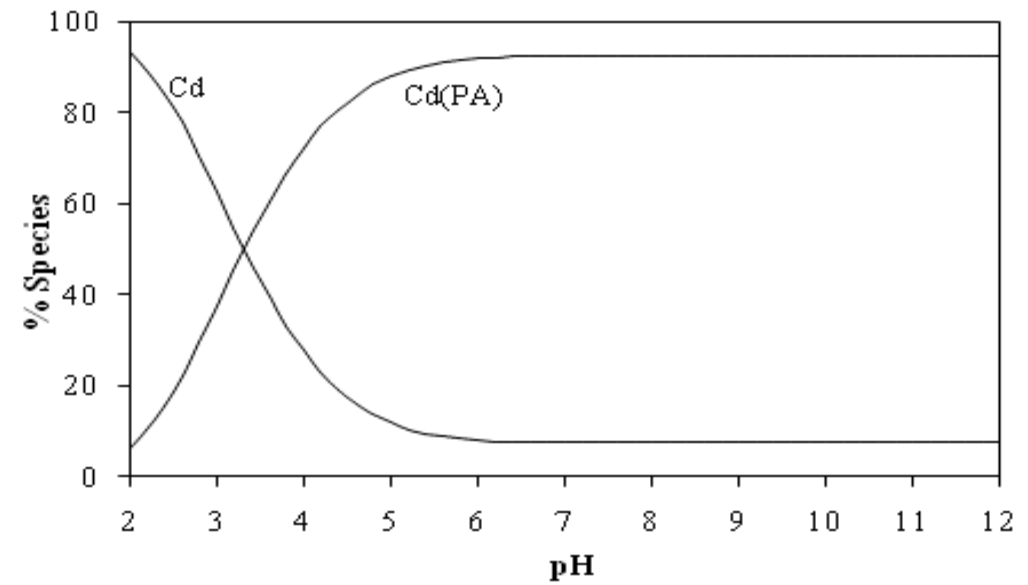

Fig.2. Concentration distribution of various species as a function of $\mathrm{pH}$ in the $\mathrm{Cd}$ (PA) system.

Ternary complex formation equilibrium

Ternary complex formation may proceed either through a stepwise or a simultaneous mechanism depending on the chelating potential of picolinic acid (PA) and other ligands. The formation constants of the 1:1 Cd(II) complexes with PA and those of amino acids and peptides, taken from the literature and cited in Table 1, are of the same order. Consequently, the ligation of PA and amino acids or peptides will proceed simultaneously. The validity of this model was verified by comparing the experimental potentiometric data with the theoretically calculated (simulated) curve. Fig. 3 presents such a comparison for the Cd-PA-alanine system, taken as a representative one. 


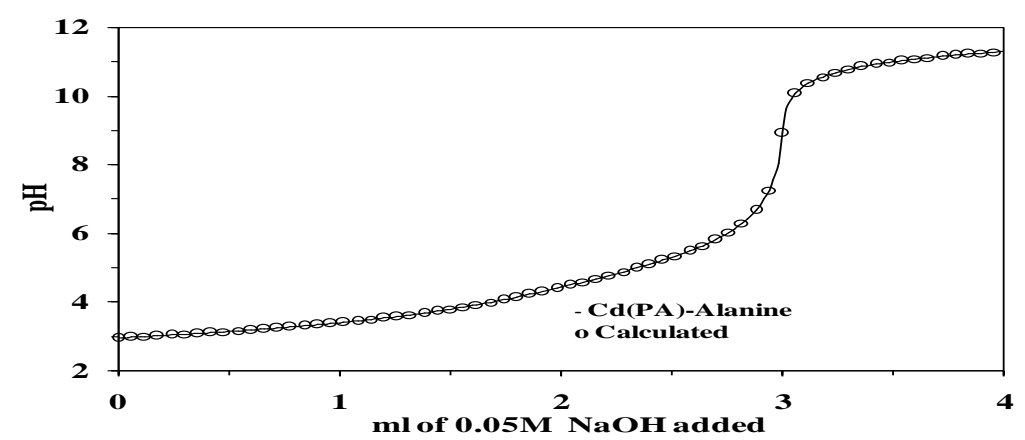

Fig.3. Potentiometric titration curve of Cd-(PA)-Alanine system.

Complex formation equilibria involving amino acids

The titration data of the ternary complexes with amino acids and PA fit satisfactorily with formation of the species: Cd-(PA), Cd-(L) and Cd-(PA)-(L). The formation constants of amino acid complexes are higher than those of the corresponding monodentate imidazole complex. This indicates that amino acids bind through their amino and carboxylate groups. Phenyl alanine forms a more stable complex than alanine, although the amino group of the phenyl alanine is less basic than that of alanine, probably due to some stacking interactions between the phenyl group of phenyl alanine and picolinic acid. This will contribute to the stabilization of the formed complex. Serine and threonine form, in addition to the previously mentioned complexes the $\mathrm{Cd}-(\mathrm{PA})-\left(\mathrm{LH}_{-1}\right)$ species. This complex is formed through induced ionization of the $\beta$-alcohol group.

The concentration distribution diagram of serine is given in Fig. 4, indicates that the species 1110 predominates in the physiological $\mathrm{pH}$ range. The ionization of the $\mathrm{OH}$ group (111-1) starts after $\mathrm{pH} \sim 6$ and predominates after $\mathrm{pH} \sim 8$.

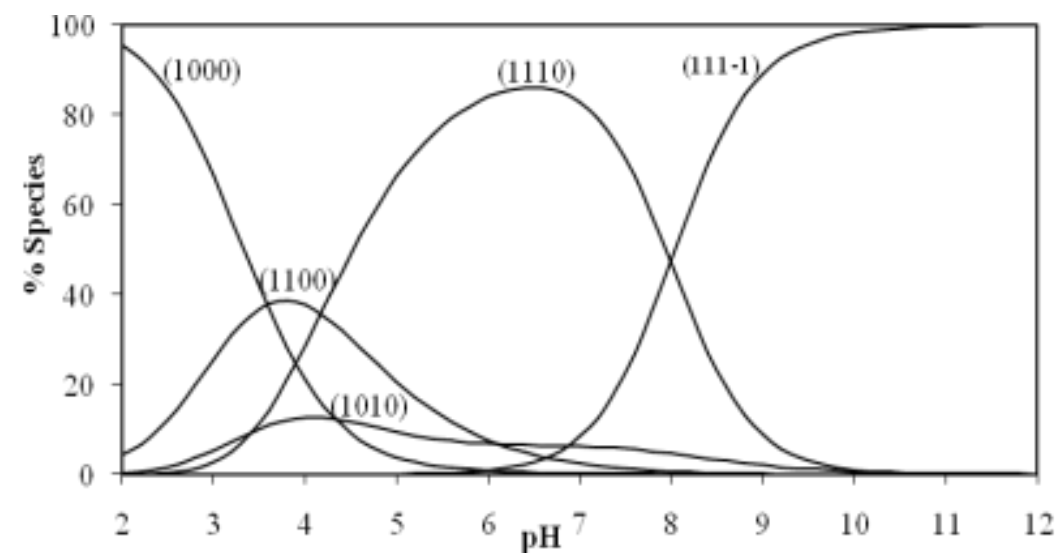

Fig. 4. Concentration distribution of various species as a function of $\mathrm{pH}$ in the $\mathrm{Cd}$ (PA)-Serine system.

Egypt. J. Chem. 59, No. 5 (2016) 
The stability constant values of histidine and histamine are of the same magnitude and are considerably higher than those of the amino acids, indicating that both histidine and histamine would coordinate preferably through the amino and imidazole groups.

Histidine, histamine, ornithine and lysine were shown to form both protonated and deprotonated complex species. The acid dissociation constant of the protonated species is given by Eq. (3).

$$
\mathrm{pK}^{\mathrm{H}}=\log \beta_{1111}-\log \beta_{1110}
$$

S-methylcysteine forms a more stable complex than methionine, plausibly due to the fact that the five-membered chelate ring in the former complex is energetically more favoured than six-membered chelate ring in the latter complex.

Ornithine and lysine may bind to $\mathrm{Cd}$ (II) ion as $\alpha$-amino acid (N,O-donor set) or by $\alpha$ - and $\square$-amino groups (N,N-donor set).The stability constants of their ternary complexes are higher than those of $\alpha$-amino acids, indicating that lysine and ornithine are ligating by the two amino groups.

\section{Complex formation equilibria involving peptides}

The potentiometric data of the $\mathrm{Cd}$ (PA) peptide system were fitted by various models. The most acceptable model was found to be consistent with the formation of the complexes with stoichiometric coefficients 1110 and 111-1. In the 1110 case, the peptide is bound through the amino and carbonyl oxygen groups. On increasing the $\mathrm{pH}$, the coordination sites should switch from the carbonyl oxygen to the amide nitrogen. The amide groups undergo deprotonation and the $\left[\mathrm{Cd}(\mathrm{PA})\left(\mathrm{LH}_{-1}\right)\right]$ complexes are formed. The $\mathrm{pK}^{\mathrm{H}}$ values are calculated by Eq. (4).

$$
\mathrm{pK}^{\mathrm{H}}=\log \beta_{1110}-\log \beta_{111-1}
$$

It is noted worthy that the $\mathrm{pK}^{\mathrm{H}}$ for the glutamine complex is relatively much higher than the others. This is due to the formation of a seven-membered chelate ring, which would be more strained and less favored. Therefore, under physiological conditions ( $\mathrm{pH}=7.4$ ) glutamine would coordinate in its protonated form. The distribution diagram of the glycylglycine complex is given in Fig. 5. The mixed ligand species [Cd-(PA)-L], (1110) starts to form at $\mathrm{pH}=3$ and, with increasing $\mathrm{pH}$, its concentration increases reaching a maximum of $42.6 \%$ at $\mathrm{pH}=4.8$. A further increase of $\mathrm{pH}$ is accompanied by a decrease in the 1110 complex concentration and an increase in [Cd-(PA)- $\left.\mathrm{LH}_{-1}\right]$, (111-1)] complex formation.

The tendency towards ternary complex formation can be evaluated in various ways. $\Delta \log \mathrm{K}$ has been widely accepted and used for comparing the stabilities of ternary and binary complexes. The $\Delta \operatorname{logK}$ value for protonated and 
deprotonated ternary complexes formed through simultaneous mechanism are given by Eq. (5) and (6) whereas those of the induce deprotonated peptide complex can be calculated using Eq. (7).

$$
\begin{aligned}
& \Delta \log \mathrm{K}=\log \beta_{1111}-\log \beta_{1100}-\log \beta_{1011} \\
& \Delta \log \mathrm{K}=\log \beta_{1110}-\log \beta_{1100}-\log \beta_{1010} \\
& \Delta \log \mathrm{K}=\log \beta_{111-1}-\log \beta_{1100}-\log \beta_{101-1}
\end{aligned}
$$

It is worthy to mention that positive $\Delta \log \mathrm{K}$ values (Table 2) for the mixedligand complexes indicate that the ternary complexes are more stable than the corresponding binary complexes, and this may be attributed to inter ligand interactions ${ }^{(28)}$ occur in the ternary complexes. On the other hand, negative $\Delta$ $\log \mathrm{K}$ values for the mixed-ligand complexes imply that the ternary complexes are less stable than the corresponding binary ones, and therefore can be used to indicate that no interaction occurs between the ligands in the ternary complexes. However, this does not mean that the negative value $\Delta \log \mathrm{K}$ precludes the formation of ternary complexes in solution ${ }^{(29-31)}$. In this regards, the negative value may be interpreted in terms of higher stability of the binary complexes and/or reduced number of coordination sites in the ligand. Other electronic and structural factors ${ }^{(32,33)}$, bond type and geometrical configuration are also expected to have an effect on $\Delta \operatorname{logK}$ values.

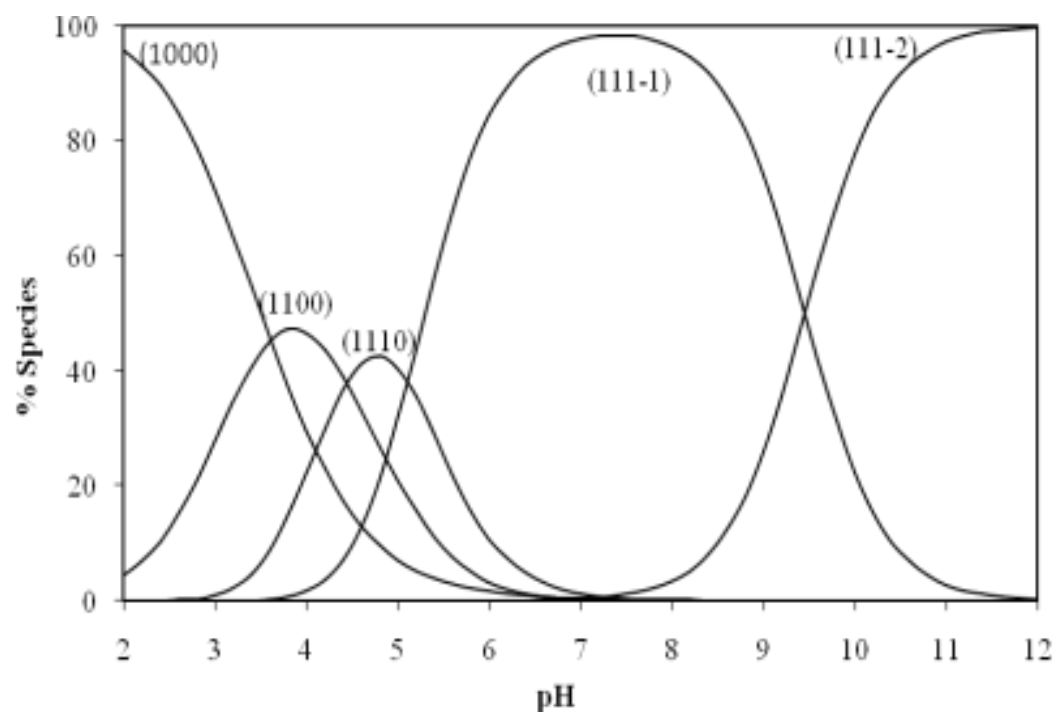

Fig.5. Concentration distribution of various species as a function of $\mathrm{pH}$ in the $\mathrm{Cd}$ (PA)-Glycylglycine system.

Complex formation equilibria involving DNA units

The complex formation equilibria of the ternary complexes involving $\mathrm{Cd}(\mathrm{II})$, PA and some selected nucleic acid bases, nucleosides and nucleotides. Such as uracil, uridine, adenine, guanosine, guanosine -5'-monophosphate, inosine, 
inosine- 5'-monophosphate have been investigated. Their stability constants have been calculated and are given in Table 2.

The binary Cd (II)-DNA complexes have also been studied. The results reveal the formation of 1:1 complexes in solution, the stability constants of which are given in Table 1. There is enough evidence to show that mixed ligand complexes of $\mathrm{Cd}(\mathrm{II})-\mathrm{PA}$ and DNA are apparently formed in a stepwise mechanism involving the interaction of $\mathrm{PA}$ with $\mathrm{Cd}(\mathrm{II})$ in a first step, followed by the inclusion of DNA as shown in Eq. (8) and (9).

$\mathrm{Cd}+\mathrm{PA} \rightleftharpoons \mathrm{Cd}(\mathrm{PA})$

$\mathrm{Cd}(\mathrm{PA})+\mathrm{D} \rightleftharpoons \mathrm{Cd}(\mathrm{PA}) \mathrm{D}$

In the ternary complexes of DNA constitutents, (D), the potentiometeric titration curves of the mixed ligand system $\mathrm{Cd}^{\mathrm{II}}-\mathrm{PA}-$ uracil (as a representative of DNA species)are shown in Fig. 6. In this respect, the formation of a ternary complex was ascertained by comparison of the mixed-ligand titration curve with the composite curve obtained by graphical addition of uracil titration data to that of the Cd ${ }^{\text {II }}-\mathrm{PA}$ titration curve. The mixed ligand system was found to deviate considerably from the resulted composite curve, indicating the formation of a ternary complex.

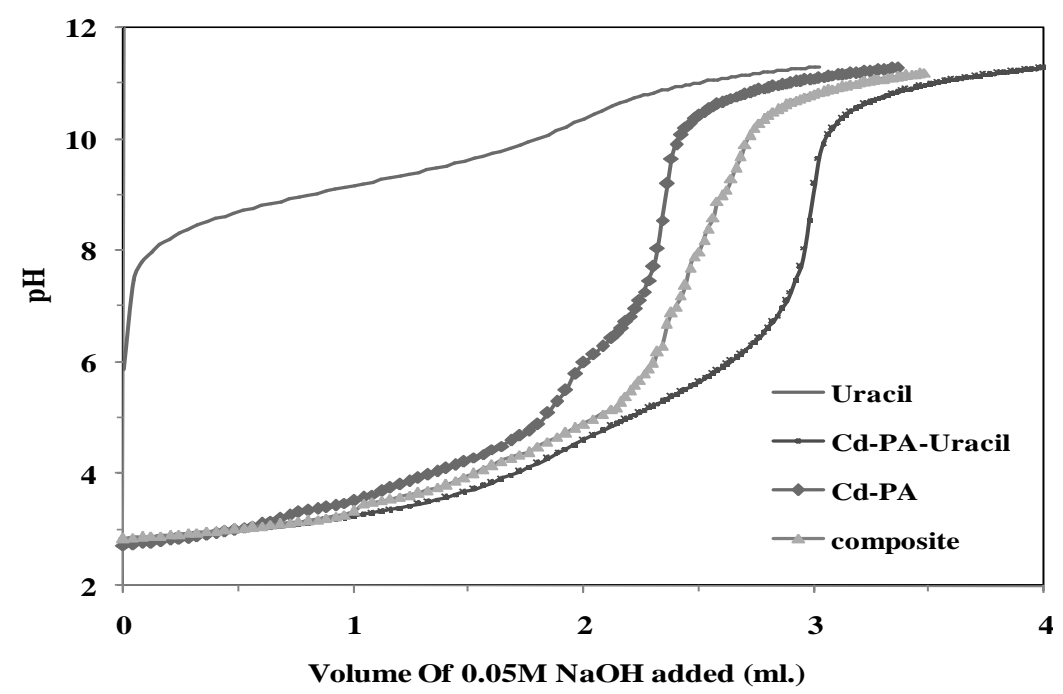

Fig.6. Potentiometeric titration curve of the Cd(II)-PA-uracil system.

Inosine and inosine-5'-monophosphate (IMP) may bind through $\mathrm{N}_{1}$ and $\mathrm{N}_{7}$ donor atoms. Spectroscopic measurements ${ }^{(34,35)}$ proved that $\mathrm{N}_{1}$ is the binding site in basic medium. In the $\mathrm{pH}$ range 7-9, inosine and IMP are assumed to bind through the $\mathrm{N}_{1}$ atom in the mixed-ligand complex formation. It should be 
mentioned that the nucleotide IMP is more stable than those of the pyrimidine. This may be explained on the basis of different coulombic forces operating between the ions. IMP is tri negatively charged, where as inosine is mono negatively charged under the selected conditions. The potentiometric data of the mixed-ligand complexes involving uracil, and uridine, are fitted assuming that these ligands are bound in the deprotonated form, most probably through the $\mathrm{N}_{3}$ atom, as previously reported ${ }^{(36)}$.

\section{Conclusion}

The present investigation may have important biological implications. The stability of Cd-PA complex may encourage the use of picolinic acid as an antidote to release $\mathrm{Cd}(\mathrm{II})$ ion.

\section{References}

1. Flick, D. F., Kraybill, H.F. and Dimitroff, J. M., Toxic Effects of Cadmium: A Review. Environ. Res. 4,71-85 (1971).

2. Gunn, S.A. Gould, T. C. and Anderson, W. A. D., Bull. Pathol. 8, 89-96 (1967).

3. Schroeder, H. S. and Balassa, J.J., Am. J. Physiol. 209, 433-437 (1965).

4. Baron, L. and Bruggs, R. Bull. Environ. Contam. Toxicol. 14, 159-162 (1975).

5. Sugawar, C. and Sugawara, N. Bull. Environ. Contam. Toxicol. 14, 159-173 (1979).

6. Dressing, S. A. Mass, R. R. and Weiss, C. M., Bull. Environ. Contam. Toxicol. 28, 172-180 (1982).

7. Titus, J.A. and Pfister, R.M., Bull. Environ. Contam. Toxicol. 28, 701-703 (1982).

8. Margoshes, M. and Vallee, B. L., J. Am. Chem. Soc. 79, 4813-4814 (1957).

9. Kagi, J. H. R. and Vallee, B. L., J. Biol. Chem. 236, 2435-2442 (1966).

10. Byerrum, R. U., Anwar, R. A. and Hoppert, C. A., J. Am. Water Works Assoc. 52, 648-651 (1960).

11. Rabenstein, D. L., Isab, A. A., Kadima, W. and Mohanakrishnan, P.A. , Biochim. Biophys. Acta. 762,531-541 (1983).

12. Schubert, J. , Ann. Rev. Nucl. Sci. 5,361-364 (1955).

13. Heller, H. J. and Catsch, A., Strahlentherapie 109,464-482 (1959).

14. Moustafa,A.G., Badawi, A.M., Shoukry,E.M., Amin, M. F. and Mostafa, M. M., Inorg. Chem. : J. Indian 10,135-141(2015).

Egypt. J. Chem. 59, No. 5 (2016) 
15. Badawi, A.M., Shoukry,E.M. Amin,M.F., Mohamed, M.A., Moustafa,A.G. and Mostafa, M. M., Inorg. Chem.: J. Indian 10, 66-72(2015).

16. Shoukry, E.M., Amin, M.F., Badawi, A.M., Mohamed, M.A. and Ahmed, A.G., Egypt. J. Chem. 57 (5), 6, (2014).

17. Ammar, R.A., Nafady, A., Amin, M. F., Al-Mogren1,M. M. and Shoukry,E.M., Int. J. Electrochem. Sci. 8 , 1501 - 1510 (2013).

18. Amin, M. F. , J.Chem.Chem.eng. 7, 591 (2013).

19. Lahsasni, S.A., Ammar, R.A., Amin, M.F. and Shoukry, E.M., Int. J. Electrochem. Sci. 7, 7699-7711 (2012).

20. Shoukry, E.M. and Amin, M. F., Modern Applied Science 5,71-81 (2011).

21. Shoukry, E.M., Ali, R.A. and Mostafa, M.M., Egypt. J. Chem. 6,52 (2009).

22. Shoukry, E.M., Bioinorganic Chemistry and applications ,USA, 2009,1(2009).

23. Welcher, E. J., Van Nostrand, Princeton, (1965).

24. Vogel, Text Book of Quantitative Chemical Analysis; $5^{\text {th }}$ ed.; Longman: UK, Chapter 15, p 555 (1989).

25. Shoukry, M. M. Hosny, W. M. and Khalil, M. M., Transition Met. Chem. 20, 252-255 (1995)

26. Gans, P., Sabatini, A. and Vacca, A., Inorg. Chim. Acta 18, 237-239 (1976).

27. Pettit, L.,University of Leeds, personal communication.

28. Rastogi, P. R., Singh, M. and Nayan, R., J. Indian Chem. Soc. 68, 158-161 (1991).

29. Reddy, P. R. and Reddy, H. M., Polyhedron 2, 1171-1175 (1983).

30. Reddy, P. R. and Reddy, H. M., J. Chem. Soc., 233-239 (1985).

31. Sigel, H., Angew Chem. Int. Edn. Engl. 14, 394 (1975).

32. Shoukry, M.M., Mohamed, M., Shehata, M. R. and Mohmoud, A.M. Mikrochim. Acta. 129,107-113 (1998).

33. Shoukry, M. M., Khairy, M. E. and Khalid, R. G., Transition Met. Chem. 22, 465-472 (1997).

34. Maskos, K., Acta Biochem. Pol. 28, 318 (1981).

35. Maskos, K., J. Inorg. Biochem. Pol. 25, 1(1985). 
36. Lim, M. C., J. Inorg. Nucl. Chem. 43, 221 (1981).

(Received 19/5/2016;

accepted20/6/2016)

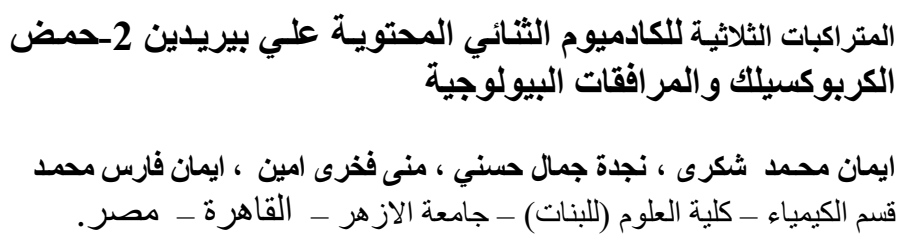

تم فى هذا البحث دراسة اتزانات تكوين مثر اكبات الكادميوم الثنائي والمحتوية

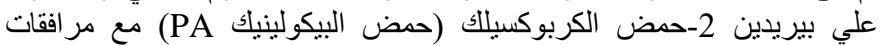

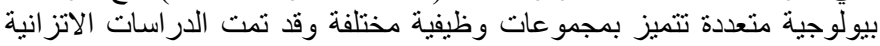

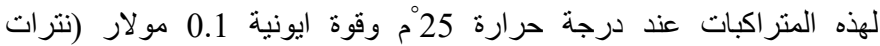

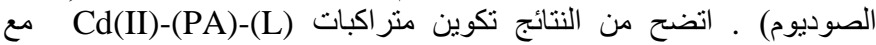

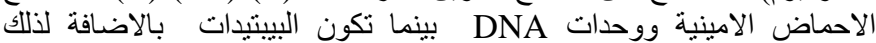

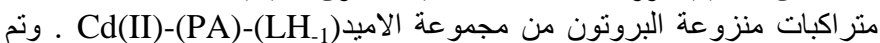

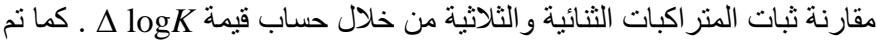

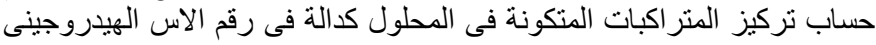

للوسط. 